\title{
The European Union Strategy for the Baltic Sea Region - An example of better and more effective regional governance
}

\begin{abstract}
The international cooperation in the Baltic Sea region, especially between Scandinavian countries, has a very long tradition that has impacted significantly on institutionalisation of regional international relations. The current European Union Strategy for the Baltic Sea Region is the first macro-regional strategy within the EU, based on the earlier regional experience. Its main goal is strengthening cooperation in this region and promoting sustainable development in order to meet common challenges. The Strategy has brought better coordination and effectiveness of the existing cooperation and turned out to be a very efficient and successful tool. Until spring 2014 the Baltic Sea Region was perceived as a model region for successful transformation, close regional cooperation, trade and inclusive security. However, it is now facing new challenges connected with changing political situation (EU-Russia relations, Brexit, migrations, etc.). The rules and forms of the governance in the Baltic Sea Region have appeared to be effective and sufficient in successfully addressing economic, social and political challenges. This is the answer to the question if there is any evidence to acknowledge the rules, forms and ways of cooperation as a model which possibly could be followed elsewhere. As a result, the EU has introduced three more macro-regional strategies.
\end{abstract}

Keywords: Baltic Sea Region, EUSBSR, governance, cooperation, international relations

\section{Strategia Unii Europejskiej dla regionu Morza Bałtyckiego - przykład lepszego i efektywniejszego zarządzania}

\section{Streszczenie}

Współpraca międzynarodowa w regionie Morza Bałtyckiego, a w szczególności państw skandynawskich, ma bardzo długą tradycję i wpłynęła na instytucjonalizację regionalnych stosunków międzynarodowych. Obecna Strategia Unii Europejskiej dla regionu 
Morza Bałtyckiego jest pierwszą makroregionalną strategią UE, opartą na wcześniejszych doświadczeniach. Jej głównym celem jest wzmacnianie współpracy w regionie i promowanie zrównoważonego rozwoju, aby sprostać wspólnym wyzwaniom. Strategia przyniosła lepszą koordynację i efektywność istniejącej współpracy. Do wiosny 2014 r. region Morza Bałtyckiego był postrzegany jako region modelowy dla uwieńczonej sukcesem transformacji, bliskiej współpracy regionalnej, wymiany handlowej i bezpieczeństwa. Jednak obecnie staje on w obliczu nowych wyzwań związanych ze zmieniającą sie sytuacją polityczną (relacje UE-Rosja, brexit, migracje itp.). Zasady i formy zarządzania w regionie Morza Bałtyckiego okazały się być efektywne i wystarczające, aby sprostać problemom ekonomiczno-społeczno-politycznym. Jest to też odpowiedź na pytanie, czy jest jakiś dowód na istnienie modelowych reguł, form i sposobów współpracy, które mogłyby być powielane. Rezultatem tego jest wprowadzenie kolejnych trzech unijnych strategii makro-regionalnych.

Słowa kluczowe: region Morza Bałtyckiego, SUERMB, zarządzanie, współpraca, stosunki międzynarodowe

There are a lot of books and research concerning the main organisations (UN, NATO, EU), however, the area of the Baltic Sea Region is not so well described. The changing circumstances bring new challenges and new problems to solve while some of them remain the same. Therefore, the question of the governance in this new environment seems to be very important. Especially the issue of the Baltic Sea Region is regarded as vital both due to its proximity and its model role of effective cooperation between all the levels.

The Baltic Sea Region has 85 million inhabitants (17 percent of EU population) in eight EU countries (Sweden, Denmark, Estonia, Finland, Northern Germany, Latvia, Lithuania, Poland) which share common features and challenges ${ }^{1}$. Also, Norway and Iceland plus two Russian regions (Kaliningrad and St. Petersburg) are considered as a part of this region. Hence, there is a clear need for joining forces and working together. A key objective of cooperation in the Baltic Sea Region is a permanent progress of living conditions and common work of the nations to obtain goals of sustainable development which consists of three dimensions: economic, social and ecological ${ }^{2}$. Besides the governmental organisations and initiatives, a lot

\footnotetext{
1 EU Strategy for the Baltic Sea Region, https://www.balticsea-region-strategy.eu/about, access 10.04.2017.

2 D. Rossa-Kilian, D. Rossa-Kilian, Wielostronna współpraca w regionie Morza Bałtyckiego na przełomie XX i XXI wieku, Wydawnictwo A. Marszałek, Toruń 2009, p. 222.
} 
of other regional networks and organisations were established after $1990^{3}$. There appears a question whether the Baltic approach to problems' solving is innovative? Are the Baltic regional cooperation and the European Union Strategy for the Baltic Sea Region good examples of multi-level governance?

The European Union Strategy for the Baltic Sea Region (EUSBSR) demonstrates the commitment and importance assigned by the countries in the region to achieve it and strengthen their position on the global stage. The EU strategy's goals of economic growth and increased prosperity in the Baltic Sea Region are important and partnerships are considered as central to create an innovative region. Making partnerships between the different policy areas and including all the levels of governance are absolutely crucial to achieve a successful implementation of all three priorities of the EUSBSR: 'Save the Sea, 'Connect the Region' and 'Increase Prosperity' which contributes to the sustainable development and growth of the region. The Strategy is welcoming cooperation also with the EU neighbouring countries: Iceland, Norway, Russia (already involved in the regional cooperation in many organisations) and Belarus.

The EUSBSR provides an integrated framework for improving the environmental condition, transport or energy interconnections as well as facilitating the development of competitive markets across borders and common networks for research and innovation. Moreover it deals with the well-being and social aspects as well as improving the attractiveness of the region. The Strategy shows the commitment of partners at different levels. According to the European Commission's assessment, 'the Strategy is already contributing positively to enhance cooperation in the Region'4. The Strategy aims to strengthen the BSR position, to increase the awareness of the region, to promote the results it delivers, to measure the impact it gives, to show the benefits it provides for countries involved and to lower the threshold for people to join the actions. The implementation of the EUSBSR is supported by an effective, modern and smart communication ${ }^{5}$.

The European Council endorsed the EU Strategy for the Baltic Sea Region (EUSBSR) in 2009, three further macro-regional strategies (MRS) have been developed: the EU Strategy for the Danube Region (EUSDR) in 2011, the EU Strategy for the Adriatic and Ionian Region (EUSAIR) in 2014 and the EU Strategy for the Alpine Region (EUSALP) in 2016.

\footnotetext{
3 K. Dośpiał-Borysiak, Polityka Finlandii i Szwecji w regionie Morza Bałtyckiego, Wydawnictwo A. Marszałek, Łódź-Toruń 2006, p. 330-346. There are more than 100 regional organisations.

4 http://www.balticsea-region-strategy.eu/about, access 18.02.2017.

5 Communication Strategy for the European Strategy for the Baltic Sea Region, p. 2, http://www.balticsea-region-strategy.eu/attachments/article/590733/EUSBSR_Communication_Strategy_final_Dec2015. pdf, access 20.02.2017.
} 


\section{Genesis of the EU initiatives in the Baltic Sea region}

The EU has created one of the most developed systems of supporting regional development. An important change in relations of the EU regions appeared together with the Maastricht Treaty signed in 1992 which established the Committee of the Regions, an advisory body for the Commission and the Council of the $\mathrm{EU}^{6}$. It was an answer to new regionalism that has brought quantitative and qualitative increase of international bodies and organisations (not only economic ones).

The Baltic Sea Initiative was adopted by the Commission to strengthen political stability within the region and its economic development. The initiative was prepared at the request of the European Council held in December $1995^{7}$ which invited the Commission to propose a suitable regional cooperation initiative to be presented to the Heads of State and the Government of the CBSS at their conference in Visby on 3-4 May $1996^{\circ}$. At that time only Denmark, Finland, Germany and Sweden were the EU members. The main areas of cooperation were: enhancing stability and democracy in the region, economic cooperation (trade, investments, and cooperation), activities in the priority areas (such as infrastructure, transportation, energy, nuclear safety, environmental protection, and tourism), and strengthening cross-border cooperation. The non-EU members participated in the so-called 'soft-projects' which elaborated recommendations, guidelines and strategies based on successful and approved methods from the western countries. The organisations creating the fora for discussion, exchange of experiences and promoting experts' cooperation were very important for the region ${ }^{10}$.

The Northern Dimension, a joint action between the EU, Iceland, Norway and Russia, was initiated and submitted by the Finnish Government in $1997^{11}$ and approved by the Council of the European Union in Madrid in 1999. The Northern

6 A. Kuształ, Polityka regionalna UE jako przykład funkcjonowania organizacji integracji regionalnej $w$ Europie, in: Regionalizacja w stosunkach międzynarodowych, ed. J. Brylewska, Wydawnictwo A. Marszałek, Toruń 2008, p. 251.

7 P. Van Elsuwege, From Soviet Republics to EU Member States: A Legal and Political Assessment of the Baltic States' Accession to the EU, Vol. 2, p. 182. There were two basic documents from 1994: 'Orientations for a Union Approach towards the Baltic Sea Region' and 'Current State of and Perspectives for co-operation in the Baltic Sea Region'.

8 Ibidem. There were two basic documents from 1994: 'Orientations for a Union Approach towards the Baltic Sea Region' and 'Current State of and Perspectives for co-operation in the Baltic Sea Region'.

9 CBSS, www.cbss.st/documents/euand_baltic_region, access January 2006.

10 J. Kukułka, Historia współczesnych stosunków międzynarodowych 1945-2000, Wydawnictwo Naukowe Scholar, Warszawa 2005, p. 500.

${ }^{11}$ J. Nowiak, Wspótpraca nordycka - wzór dobrej polityki, Wydawnictwo Naukowe Wyższej Szkoły Nauk Humanistycznych i Dziennikarstwa, Poznań 2001, p. 181. 
Dimension aimed to strengthen dialogue and cooperation between the partners and to provide security, stability and sustainable development as well as competitiveness. A particular emphasis was put on subsidiarity and ensuring active participation of all stakeholders including regional organisations, local and regional authorities, the academic and business communities. The main areas of cooperation were: economy; human resources, education, culture, research, health; environment, nuclear safety and natural resources; cross-border cooperation; justice and home affairs.

In November 2006 the European Parliament took a resolution on 'A Baltic Sea Strategy for the Northern Dimension' whose main aims were: 'to support the Northern Dimension policy by defining the Baltic Sea Region as one of the main priority areas, thereby promoting deeper regional integration in the Baltic Sea region, which is a viable and dynamic part of a wider European economic and political area; to make the most of the opportunities offered by the dynamic economies of the Baltic Sea Region and systematically create a brand for the region as one of the most attractive and competitive areas in the world; to help to improve the ecological status of the Baltic Sea, which is currently one of the most polluted sea areas in the world ${ }^{\prime 2}$.

The European Union Strategy for the Baltic Sea Region was approved by the Council of the European Union on 29-30 October 2009 following recommendations i.e. 'The Joint Declaration on the implementation of the EU Strategy for the Baltic Sea Region' signed on 18 September 2009 during the Swedish Presidency of the EU ${ }^{13}$. The Strategy focused on the main challenges in the region which were to ensure protection of the environment, well-being, security and availability of the region. The Strategy created a framework for multilateral cooperation in the region between all levels, all partners and stakeholders and it is closely connected to the main EU policy directions, including those mentioned in the "Europe 2020" strategy. The Strategy was also considered as a useful tool in cooperation with the neighbouring countries. As the European Council conclusions noted, the Northern Dimension - a common policy of the EU, Russia, Norway and Iceland - provides the basis for external aspects of the Strategy. For other international bodies such the Council of the Baltic Sea States (CBSS), the Nordic Council of Ministers (NCM) or HELCOM it is useful as well.

12 A Baltic Sea Strategy for the Northern Dimension, http://www.europarl.europa.eu/sides/getDoc. do?pubRef=-//EP//TEXT+TA+P6-TA-2006-0494+0+DOC+XML+V0//EN, access 24.04.2017.

${ }_{13} \mathrm{http} / /$ ec.europa.eu/regional_policy/sources/cooperate/baltic/doc/stockholm_declaration.pdf, access 24.04.2017. 


\section{European Union Strategy for the Baltic Sea Region}

The EUSBSR is the first macro-regional strategy in Europe. Its main goal is to strengthen cooperation in this region and promote sustainable development in order to meet common challenges. The Strategy is divided into three objectives (previously 4 pillars) which represent the three key challenges: Saving the Sea, Connecting the Region and Increasing Prosperity. Each objective relates to a wide range of policies and has an impact on the other objectives. The work carried under the Policy Areas involves stakeholders from all the levels (international, national, regional, local) and sectors (public, private, civil society). It is structured around joint actions and illustrated by the flagships. The Strategy also includes the Horizontal Actions which have a more cross-cutting character and are relevant for many objectives, the examples can be cooperation on spatial planning or adaptation to the climate change. The Horizontal Actions complement the objectives and policy areas. The CBSS has coordinated cooperation between different stakeholders and was responsible for collecting opinions from these organisations in order to prepare the EUSBSR. In addition, the CBSS facilitates the access to EU financing ${ }^{14}$.

The EUSBSR appears to build upon and to promote ideas of territorial cohesion, coherence and cooperation. However, it does not supply any new instruments, legislation or funding. Instead it collects and highlights diverse and often already existing initiatives and instruments within a Baltic Sea Region framing, adding a macro-regional perspective ${ }^{15}$. At the same time, this lack of additional funds ${ }^{16}$ is the reason for better coordination and governance or just a necessity that legitimates existence of this initiative.

The Strategy ensures better coordination and gives support for the member states to focus on the main challenges and problems. The EU in its Communication included concrete proposals to establish a set of measurable indicators and targets for each objective, with the aim of facilitating monitoring, evaluation, communication, and, most importantly, achieving results. On 26 June 2012, the General Affairs Council endorsed this Communication ${ }^{17}$ and took note of the list of indicators and

14 German Presidency of the Council of the Baltic Sea States 2011/2012 Programme of Work, Berlin 2011, p. 3.

15 J. Metzger, P. Schmidtt, When Soft Spaces Harden: The EU Strategy for the Baltic Sea Region, p. 4, http://www.diva-portal.org/smash/get/diva²:452279/FULLTEXT01.pdf, access 20.04.2017.

16 The Macro-regional Strategies Have Not Got Any Additional Funds from the EU Budget.

17 Council Conclusion on the Competition of the Review of the EUSBSR, 26.06.2012, Luxembourg, http://www.consilium.europa.eu/uedocs/cms_Data/docs/pressdata/EN/genaff/131228.pdf, access 11.04.2017. 
targets. Following this, the Action Plan of the EUSBSR was updated to reflect this list and in order to be fully in line with and contribute to the objectives of the Europe 2020 Strategy.

The Action Plan introduced governance of the EUSBSR in line with the guidelines for roles and responsibilities of the main implementing actors. These groups represent the core of the overall initiative and the functioning of the Strategy. The following paragraphs briefly describe the main areas of responsibility of some key actors of the Strategy. 'The Member States and National Coordinators (Ncs) involved in the Strategy are implicated at all levels by having an active political engagement, encouraging participation of stakeholders and ensuring the visibility of the EUSBSR within their countries. The European Council, the European Commission and the High-Level Group of macro-regional strategies have the main political role. They take the Strategy into account in relevant policy initiatives, promote the dialogue between stakeholders and contribute to reviewing and updating the Action Plan. The overall coordination of the Strategy lies on the Policy Area Coordinators and Policy Area Focal Points as well as Horizontal Action Coordinators and Horizontal Action Focal Points are the key responsible for the application of the necessary measures to guarantee the success and visibility of the Strategy" 18 .

At an operational level, there are different programmes and bodies involved in the Strategy. The Strategy includes Programmes under the EU Cohesion Policy as well as European Neighbourhood and Partnership Instrument (ENPI) programmes and other financial instruments e.g. the European Investment Bank. The implementation and promotion of flagships with a high macro-regional impact in the Baltic Sea Region contribute to fulfilling the objectives of the Strategy. The EUSBRS target groups have been split into the following groups:

- internal groups: European Commission and other EU institutions, Member States /National Coordinators, Policy Area Coordinators/Horizontal Action Coordinators, Leaders and partners within flagships, Local and regional actors/ communities, also NGOs (also under external groups)

- external groups: Policy makers on a national, regional and local level; Private companies (businesses), General public, especially in local and regional communities, attracting relevant partners, beneficiaries - a new group of actors not directly involved in EUSBSR right now but having a large network and a real connection to the Baltic Sea Region such as photographers, NGO activists, authors, researchers and students.

18 EUSBSR, Governance, http://www.balticsea-region-strategy.eu/governance, access 12.04.2017. 
The main regional challenge - an improvement of the environment of the Baltic Sea - has remained unchanged. However, further efforts are needed taking into account the environmental challenges faced by the Baltic (eutrophication, nitrates from agricultural sources, fisheries). The region could also benefit from improved connectivity in the fields of energy and transport and better response to impacts of climate change ${ }^{19}$. Also new challenges like the rapid increase in migrants or threads from Russia need further discussion and appropriate actions. Policy making could be improved by a number of operational measures, for instance: facilitating the management and sustainability of projects, strengthening the contribution of horizontal actions to implementation of each policy area; reinforcing the link between project and policy levels.

The additional aspect to be solved is the fact that the policy agenda in the European Union is being shaped differently. At the national level the agenda is under greater influence of politicians who are closely interconnected with voters. At the European Union level the technocratic (not directly elected) European Commission has a monopoly of legislative initiative ${ }^{20}$. The Strategy does not have a dedicated budget of its own. Therefore, it requires a more coordinated use of available funding streams at different levels.

'The commission, in close co-operation with the governments and other stakeholders concerned, has made a number of proposals to ensure effective implementation of the actions and projects that can really make a difference in the region. This starts with the preparation of an action plan, drawn from proposals made by commission services, national administrations, regions, NGOs and other stakeholders. The actions are selected on the basis of being ready for rapid implementation, or at least launching, involving a number of partners from different Member States in the region, and most importantly taking advantage of the opportunities or countering the threats identified as significant in the region ${ }^{21}$.

A considerable number of regional organisations, networks and initiatives are involved in the EUSBSR. They play an important role i.e. as policy area/horizontal area coordinators who are involved in flagships and other activities. The EUSBSR provides a wider strategic and institutional framework, while benefiting from their

19 Report from the Commission to the European Parliament, the Council, the European Economic and Social Committee and the Committee of the Regions on the Implementation of EU macro-regional Strategies, p. 6, http://ec.europa.eu/regional_policy/sources/cooperate/macro_region_strategy/pdf/report_implem_macro_region_strategy_en.pdf, access 24.04.2017.

${ }_{20}$ G. Majone, Public Policymaking and its Analysis at National and European Levels, "Studia z Polityki Publicznej/Public Policy Studies" 2015, No. 2(6), p. 9.

21 J. Karnowski, Partnerstwo $w$ regonie - modny slogan czy determinanta rozwoju, w: Partnerstwo w regonie, red. J. Karnowski, Uniwersytet Szczeciński, Szczecin 2004, p. 146. 
experience and expertise ${ }^{22}$. Innovation is of key importance to the Baltic Sea region as a driving force of increased prosperity, it is highly relevant to realising the potential of all of the 3 Objectives $^{23}, 13$ Policy Areas ${ }^{24}$ and 4 Horizontal Actions ${ }^{25}$ established $^{2}$ by the EUSBSR ${ }^{26}$. The macro-regional collaboration is underpinned by the BSR countries' proximity, in terms of both geography and culture. The macro-region's geographical proximity creates opportunities by forming regional value chains that build on the respective strengths of the different parts of the region. Proximity can also enable close integration, which would give the macro-region greater critical mass and allow it to compete in global markets for skills and investment. Countries with cultural proximity - expressed as sharing similar cultures and having a deep knowledge of each other - find it easier to learn from each other. In the context of the BSr, the macro-regional collaboration that has existed since 2009 has increased this proximity by bringing about an enhanced understanding of our differences and

22 EUSBSR Action Plan 20.3.2017, p. 22-32, http://www.balticsea-region-strategy.eu/communication/ news/590821-updates-to-the-eusbsr-action-plan, access 17.04.2017. The main organisations involved: BSC CPMR, Baltic Sea Parliamentary Conference, Baltic Sea NGO Network, Baltic Sea States Subregional Co-operation, Baltic Development Forum, BONUS, CBSS, HELCOM, Northern Dimention, Nordic Council of Ministers, Union of the Baltic Cities, VASAB.

23 EUSBSR Action Plan 20.3.2017, http://www.balticsea-region-strategy.eu/communication/news/ 590821-updates-to-the-eusbsr-action-plan, access 19.04.2017.

OBJECTIVE: Save the Sea / SUBOBJECTIVE: Clear water in the sea; Rich and healthy wildlife; Clean and safe shipping; Better cooperation; OBJECTIVE: Connect the Region / SUBOBJECTIVE: Good transport conditions; Reliable energy markets; Connecting people in the region; Better cooperation in fighting cross-border crime; OBJECTIVE: Increase Prosperity / SUBOBJECTIVE: Baltic Sea region as a frontrunner for deepening and fulfilling the single market; EUSBSR contributing to the implementation of Europe 2020 Strategy; Improved global competitiveness of the Baltic Sea region; Climate change adaptation, risk prevention and management.

${ }^{24}$ EUSBSR Action..., op. cit. Policy Areas: PA Bioeconomy - Agriculture, forestry and fisheries; PA Culture - Culture \& creative sectors; PA Education - Education, research and employability; PA Energy - BEMIP Action Plan (for competitive, secure and sustainable energy); PA Hazards - Reducing the use and impact of hazardous substances; PA Health - Improving and promoting people's health, including its social aspects; PA Innovation - Exploiting the full potential of the region in research, innovation and SME, utilising the Digital Single Market as a source for attracting talents and investments; PA Nutri - Reducing nutrient inputs to the sea to acceptable levels; PA Safe - To become a leading region in maritime safety and security; PA Secure - Protection from land-based emergencies, accidents and cross-border crime; PA Ship - Becoming a model region for clean shipping; PA Tourism - Reinforcing cohesiveness of the macro-region through tourism; PA Transport - Improving internal and external transport links.

${ }^{25}$ EUSBSR Action..., op.cit., Horizontal Actions: HA Capacity - Capacity building and involvement; HA Climate; HA Neighbours - Creating added value to the Baltic Sea cooperation by working with neighbouring countries and regions; HA Spatial Planning - Encouraging the use of maritime and landbased spatial planning in all Member States around the Baltic Sea and develop a common approach for cross-border cooperation.

26 Policy Area Innovation Strategy Guide 2016-2020, Nordic Council of Ministers, Denmark 2016, p. 6, http://www.bdforum.org/wp-content/uploads/2016/09/Policy-Area-Innovation-Strategy-Guide.pdf, access 21.04.2017. 
similarities. This has proven critical to transnational collaboration on policy and demonstrates that the region is ripe for further development of the collaboration ${ }^{27}$.

A key factor of success for the Strategy is the integrated and coordinated governance of the Baltic Sea region, between sectors of society as well as between regional and local authorities in the respective countries. Without such integration, the objectives of the Strategy would be difficult to achieve. The overall success of the strategy also depends on the weight and attention that is given by the political actors in the region. In a number of cases, the objective of the actions and flagships is to highlight areas of activity that are ongoing within the EU or in other international frameworks, but which require greater coordination within the Baltic Sea region and consistent funding strategies to be implemented successfully. The Strategy provides a unique opportunity to do this ${ }^{28}$. The macro-regional cooperation is a kind of the decision-making mechanisms for these respective bodies. As regards cooperation with Russia, developments in EU-Russia relations will be taken into account in accordance with the relevant European Council and Council Conclusions.

Moving from the enabling of shared learning towards joint programmes and investments requires an increasing level of co-ordination and the submission of own resources to the control of joint decision-making ${ }^{29}$. Macro-regional collaboration is always a challenge in and of itself, but in the case of the BSr, such collaboration can draw upon both geographic and cultural proximity in a way that most macro-regions cannot. Furthermore, the individual communities in the BSR already rank very high in most global innovation rankings ${ }^{30}$.

In quickly changing geopolitical conditions it is possible to observe an increase of interest in practical aspects concerning current international system and its functioning. In order to prevent conflicts and/or to solve them the states established international organisations which serve as the platforms of cooperation and the guards of the shared values. In the 20th century one of the commonly used means for securing international stability and security becomes preventive diplomacy because 'one ounce of prevention is worth a pound of cure. To guarantee realization of this idea

27 Policy Area..., op.cit., p. 7.

28 European Union Strategy for the Baltic Sea Region Action Plan, Brussels 10.09.2015.

29 Policy Area..., op.cit., p. 7.

30 Ibidem, p. 9. 
of collective security, the states delegate a part of their competencies to international organisations to carry mutual dialogue at different levels ${ }^{31}$.

It is worth noticing that in comparison with other European countries the Baltic Sea Region countries, especially Scandinavian countries, much earlier than others (already in the 13th century) elaborated models of international cooperation that were connected with institutionalization of international relations. In the beginning it was economic cooperation, first of all, trade, then political and culture aspects were taken into account. It was reflected in the socio-economic and politic-cultural situation of those countries. Despite many changes of the states' systems, borders and economic transformations, the countries preserved their culture identities slightly incorporating foreign trends and tendencies. The region was not free from the conflicts and regional wars but they were reduced by cooperation, development and good governance ${ }^{32}$.

In connection with deepened cooperation and institutionalisation of international relations emerges a discussion about 'governance. The term of 'governance' might be described in comparison with the word 'government ${ }^{33}$. Both words describe a system of rules but the 'government' suggests activities which are regulated by formal authority while the 'governance' is a much wider term which regards activities not necessary regulated by any law. According to O.R. Young 'governance' is an activity of a system of rules which sets practices, assigns roles and coordinates actions to solve collective problems ${ }^{34}$. These processes which coordinate activity of involved group or institutions might be both formal as well as non-formal. In other words, the 'governance' is a sum of relations that leads to taking a specific course in a particular problematic area.

The rules and forms of the governance in the Baltic Sea Region turned out to be effective and sufficient in successfully addressing economic, social and political challenges. This is the answer to the question if there is any evidence to acknowledge the rules, forms and ways of cooperation as a model which possibly could be followed elsewhere? The effects of current cooperation in the Baltic Sea Region can be seen as satisfactory and adequate to the expectations. Moreover 'partnership in this region, which means cooperation among local government institutions, between local

31 Rola instytucjonalizacji w kształtowaniu stosunków międzynarodowych, ed. K. Żukrowska, Oficyna Wydawnicza SGH, Warszawa 2006, p. 17.

32 I. Śmigerska-Belczak, Instytucjonalizacja stosunków międzynarodowych w regionie Morza Bałtyckiego, Wydawnictwo MADO, Toruń 2014, p. 6-7, Hansa (XIII-XVII c.), Kalmar Union, XIX c. unions, etc.

33 G. Evans, R. Newnham, Penguin Dictionary of International Relations, Penguin Books Ltd, 1998, p. 209.

34 A. Polus, 'Governance' $w$ stosunkach międzynarodowych, in: Regionalizacja w stosunkach międzynarodowych. ed. J. Brylewska, Wydawnictwo A. Marszałek, Toruń 2008, p. 42. 
government and local market companies and other institutions, should be treated as a development determiner. In many fields, especially in innovation, economy and infrastructure partnership cooperation can give a synergy effect. That's why local government institutions should inspire to build partnership relations in the region ${ }^{35}$. In addition to that the successful example of the EUSBSR was transferred to three other European regions (Danube, Adriatic-Ionian and Alpine).

'For our region to prosper, the force of innovation must contribute to a sustainable development to the benefit of people living in all parts of the Baltic Sea Region while protecting our precious environment. Many of the challenges related to sustainable development faced globally are also apparent in our nearby environment. The region has a strong knowledge base and is technologically advanced in order to operate on highly competitive internal and external markets. We can therefore test new innovative solutions and their global market potential right here in the Baltic Sea Region. This requires a bottom-up approach, taking regional demand as a starting point and connecting the local regional actors in areas which they have identified as relevant for transnational collaboration ${ }^{36}$.

The EU proposed a more pragmatic approach to provide support for governance that is based on dialogue and capacity building. However, there is no one-size-fitsall solution thus there is a need for an individual approach tailored to the specific circumstances in each country. The EU concentrates on helping to:

- build institutional capacity and increasing the capacity of partner countries to take ownership of the process of drawing up and implementing programmes and appropriate reform;

- ensuring synergy and consistency between the EU's various instruments and policies in this area;

- ensuring complementarity between, and coordination of, the different donors' activities;

- helping to protect human rights and promote democracy, good governance and the rule of law.

Institutionalization of regional international relations in the Baltic Sea region enhances development of economic, social and political cooperation in the region and contributes to its overall development. The Commission and the Member States actively support the multi-level governance approach recognizing the potential

\footnotetext{
35 J. Karnowski, Partnerstwo..., op.cit., p. 138.

36 http://www.balticsea-region-strategy.eu/highlights/item/7-spotlight-on-policy-area-innovation-collaborating-on-innovation-for-a-sustainable-development-of-the-baltic-sea-region, access 18.02.2017.
} 
substantial contribution from all levels of society in implementing the macro-regional strategies ${ }^{37}$.

'Until spring 2014 the Baltic Sea Region was perceived as a model region for successful transformation, close regional cooperation, flourishing trade, and inclusive security, which is now at the center of confrontation ${ }^{38}$. The European Council endorsed the EUSBSR in 2009 and three further macro-regional strategies were developed: the EUSDR in 2011, the EUSAIR in 2014 and the EUSALP in 2016. 'Macro-regional strategies add value to the cooperation dimension of cohesion policy. They offer a platform for multi-sectoral, multi-country and multi-level governance, also open to non-EU countries. They can play a substantial role in helping these countries to strengthen their links with the EU and mitigate possible negative effects on the EU's external borders ${ }^{39}$ and also play a big role in developing links with non-EU countries, in particular accession countries. Most of these initiatives and actions would benefit from stronger coordination within and between the involved countries to deliver the expected results. The practice of combining the annual fora with ministerial meetings contributes to it, and at the same time raises the political profile. The experience of the Baltic Sea region shows that long-term strategic thinking must remain the basis for macro-regional cooperation. Macro-regional strategies generally include a threetier governance system with policy, coordination and operational levels. They focus on an optimal use of existing financial sources, better implementation of existing legislation and better use of existing institutions ${ }^{40}$, reducing regional disparities, the creation of synergies for growth and employment ${ }^{41}$.

After seven years the strategy has given impetus to new networks and brought consolidation of multi-level governance in the region that has offered the Baltic Sea actors a joint framework for dialogue ${ }^{42}$. The strategy has contributed to shaping policy at different levels and to the implementation of existing legislation. Increased cooperation and coordination at all levels has created stronger synergies. The preparation of macro-regional projects supported by transnational partnerships and networks has been helped by the launch of the EUSBSR Seed Money Facility together with the Interreg Baltic Sea Region. The establishment of a network of European Regional and Development Fund (ERDF) managing authorities in 2016 will allow a more

37 Council conclusion..., op.cit.

38 Political State of the Region Report 2016, Baltic Development Forum, Copenhagen 2016, p. 6, http://www.bdforum.org/wp-content/uploads/2016/11/Political_State_Region_Report_2016.pdf, access 21.04.2017.

39 Ibidem, p. 2.

40 Ibidem, p. 3.

41 Ibidem, p. 11.

42 Ibidem, p. 6. 
efficient use of available resources. These achievements have been supported by a comprehensive review of the EUSBSR Action Plan carried out in 2015, which led to a more streamlined and focused strategy. The review also contributed to a stronger sense of ownership by introducing a rotating chairmanship of the group of national coordinators in 2014.

The regional cooperation concentrates on the common goals. The origin of this cooperation lays in the earlier dialogue and programming. While the programmes focus on the concrete activities, the strategy has a much broader approach than the specific programmes. The European Union has been present in the Baltic Sea Region for a long time as well as the projects and the different kinds of funds/programmes. That has had an impact on shaping the regional strategy with the horizontal actions, multilateral cooperation and common policy that included partners and stakeholders from all levels. The EUSBSR is considered to have created a common framework for action and encouragement for cooperation ${ }^{43}$. The current EUSBSR strategy offers the opportunity to move from words to action and to deliver real benefits. There is the need for a common strategic vision to guide further sustainable territorial development of this region. 'It is clear that no one acting alone can apply the range of measures necessary to confront the challenges and exploit the opportunities of the region. We are convinced that a strategy for the Baltic Sea region, consisting of the approach and actions described above are essential to protect the Baltic Sea and to exploit fully the opportunities open to the region'44.

\section{Bibliography}

A Baltic Sea Strategy for the Northern Dimension, http://www.europarl.europa.eu/sides/getDoc. do?pubRef=-//EP//TEXT+TA+P6-TA-2006-0494+0+DOC+XML+V0//EN

Communication Strategy for the European Strategy for the Baltic Sea Region, http://www. balticsea-region strategy.eu/attachments/article/590733/EUSBSR_Communication_Strategy_final_Dec2015.pdf

Council Conclusion on the Completion of the Review of the EUSBSR, 26.06.2012, Luxembourg 2012, http://www.consilium.europa.eu/uedocs/cms_Data/docs/pressdata/EN/genaff/131228. pdf

Council of the Baltic Sea States, www.cbss.st/documents/euand_baltic_region

43 EUSBSR Action Plan, 20.03.2017, p. 32.

44 The European Strategy for the Baltic Sea Region - Background and Analysis, Office for Official Publications of the European Union, Luxembourg 2010, p. 11; http://ec.europa.eu/regional_policy/sources/ cooperate/baltic/pdf/2010_baltic.pdf, access 10.04.2017. 
Dośpiał-Borysiak K., Polityka Finlandii i Szwecji w regionie Morza Bałtyckiego, Wydawnictwo A. Marszałek, Łódź-Toruń 2006.

European Union Strategy for the Baltic Sea Region Action Plan, Brussels 10.9.2015.

EUSBSR - Governance, http://www.balticsea-region-strategy-eu/governance

EUSBSR - Spotlight on Policy Area Innovation: Collaborating on innovation for a sustainable development of the Baltic Sea Region.

EUSBSR - What is the EUSBSR, http://www.balticsea-region-strategy.eu/about

EUSBSR Action Plan 20.03.2017, http://www.balticsea-region-strategy.eu/communication/ news/590821-updates-to-the-eusbsr-action-plan

Evans G., Newnham R., Penguin Dictionary of International Relations, Penguin Books Ltd, London 1998.

German Presidency of the Council of the Baltic Sea States Programme of work, Berlin 2011.

http://www.balticsea-region-strategy.eu/highlights/item/7-spotlight-on-policy-area-innovationcollaborating-on-innovation-for-a-sustainable-development-of-the-baltic-sea-region

Karnowski J., Partnerstwo w regonie - modny slogan czy determinanta rozwoju, in: Partnerstwo $w$ regonie, red. J. Karnowski, Uniwersytet Szczeciński, Szczecin 2004.

Kuształ A., Polityka regionalna UE jako przykład funkcjonowania organizacji integracji regionalnej w Europie', in: Regionalizacja w stosunkach międzynarodowych, ed. J. Brylewska, Wydawnictwo A. Marszałek, Toruń 2008.

Majone G., Public Policymaking and its Analysis at National and European Levels, "Studia z Polityki Publicznej/ Public Policy Studies" 2015, No. 2(6).

Metzger J., Schmidtt P., When Soft Spaces Harden: The EU Strategy for the Baltic Sea Region, http:// www.diva-portal.org/smash/get/diva2:452279/FULLTEXT01.pdf

Nowiak J., Wspótpraca nordycka - wzór dobrej polityki, Wydawnictwo Naukowe Wyższej Szkoły Nauk Humanistycznych i Dziennikarstwa, Poznań 2001.

Policy Area Innovation Strategy Guide 2016-2020, Nordic Council of Ministers, Denmark 2016, http://www.bdforum.org/wp-content/uploads/2016/09/Policy-Area-InnovationStrategy-Guide.pdf

Political State of the Region Report 2016, Baltic Development Forum, Copenhagen 2016, http:// www.bdforum.org/wp-content/uploads/2016/11/Political_State_Region_Report_2016.pdf

Polus A., 'Governance' w stosunkach międzynarodowych, in: Regionalizacja $w$ stosunkach międzynarodowych, ed. J. Brylewska, Wydawnictwo A. Marszałek, Toruń 2008.

Report from the Commission to the European Parliament, the Council, the European Economic and Social Committee and the Committee of the Regions on the Implementation of EU macro-regional Strategies http://ec.europa.eu/regional_policy/sources/cooperate/macro_ region_strategy/pdf/report_implem_macro_region_strategy_en.pdf

Rola instytucjonalizacji $w$ kształtowaniu stosunków międzynarodowych, ed. K. Żukrowska, Oficyna Wydawnicza SGH, Warszawa 2006.

Rossa-Kilian D., Wielostronna współpraca w regionie Morza Bałtyckiego na przełomie XX i XXI wieku, Wydawnictwo A. Marszałek, Toruń 2009. 
Stockholm Joint Declaration, http://ec.europa.eu/regional_policy/sources/cooperate/baltic/ doc/stockholm_declaration.pdf

Śmigerska-Belczak I., Instytucjonalizacja stosunków międzynarodowych $w$ regionie Morza Bałtyckiego, Wydawnictwo MADO, Toruń 2014.

The European Strategy for the Baltic Sea Region - Background and Analysis, Luxembourg 2010, http://ec.europa.eu/regional_policy/sources/cooperate/baltic/pdf/2010_baltic.pdf 